\title{
Unraveling genetic variations of Dalbergia latifolia (Fabaceae) from Yogyakarta and Lombok Island, Indonesia
}

\author{
KUSUMADEWI SRI YULITA", TIKA D. ATIKAH, WITA WARDANI, SUSILA \\ Research Centre for Biology, Indonesian Institute of Sciences, J1. Raya Bogor Km. 46, Cibinong, Bogor 16911, West Java, Indonesia. \\ Tel./fax. +62-21-8765067, `email: yulita.kusumadewi@gmail.com
}

Manuscript received: 3 December 2010. Revision accepted: 30 January 2020.

\begin{abstract}
Yulita KS, Atikah TD, Wardani W, Susila. 2020. Unraveling genetic variations of Dalbergia latifolia (Fabaceae) from Yogyakarta and Lombok Island, Indonesia. Biodiversitas 21: 833-841. Dalbergia latifolia Roxb. (Fabaceae) or sonokeling is a timber species extracted for its beautiful heartwood used mainly for musical instruments. D. latifolia was listed in Appendix 2 of CITES since 1997, and the demand for its timber is increasing. The species is considered vulnerable (VU A1cd ver 2.3) to extinction according to the IUCN Red List, while cultivations were mainly done from a root cutting. To anticipate the further loss of population size while maintaining sustainable use of the species, it is essential to evaluate the genetic diversity since the genetic diversity level could serve as an indicator of plant adaptability to its environment. This present study was the first to report the genetic diversity of five populations of D. latifolia from Yogyakarta and Lombok Island, West Nusa Tenggara, Indonesia. Ten combinations of Sequence Random Amplified Polymorphism (SRAP) primers were used to amplify 48 samples of D. latifolia from five populations in Yogyakarta and Lombok Island. The 137 SRAP loci were used for a cluster, and population genetic analysis, with mean NPL, was of 13.6/locus, PLP of 56.18\%, $\mathrm{H}$ of 0.16 , and PIC for all population was of 0.28 . The lowest gene diversity $(\mathrm{H}=0.11)$ was observed in population WL 1 of Lombok Island, while the highest $(\mathrm{H}=0.20)$ was recorded for population $\mathrm{KP}$ of Yogyakarta. The Yogyakarta and Lombok populations were genetically structured at a medium level $(\mathrm{Gst}=0.27)$, with low genetic distance $(0.0310-0.1281)$, and a moderate level of variation observed among individual trees (ca. 0.5 coefficient similarity). The results of this present study were expected to provide necessary information on further research of $D$. latifolia from Indonesia to support the sustainable use of $D$. latifolia in Indonesia and the preservation of this species.
\end{abstract}

Keywords: Dalbergia latifolia, genetic variation, sonokeling, SRAP

Abbreviations: SRAP: Sequence Random Amplified Polymorphism. He: Expected Heterozygosity. NPL Number of Polymorphic Loci. PPL Percentage of Polymorphic Loci. GST: WL1: West Lombok 1. KP: Kulon Progo. CITES Convention of International Trade of Endangered Species. IUCN International Union for Conservation of Nature

\section{INTRODUCTION}

The genus Dalbergia (Fabaceae: Papilionaceae) contains ca. 250 species ( $\mathrm{Li}$ et al. 2017) that has a wide distribution in tropical and subtropical regions in South America, Africa, Asia and Madagascar (Cardoso et al. 2013; Saha et al. 2013; Vatanparast et al. 2013). Some species of Dalbergia have high-quality timber, including D. latifolia Roxb. (Indian rosewood), D. nigra (Brazilian rosewood), D. maritima (Madagascar rosewood), and $D$. odorifera (Huanghuali rosewood). Dalbergia latifolia-or sonokeling in Indonesian-is mainly distributed in Java and West Nusa Tenggara. Few populations are recorded in Timor Island, South Sumatra, and Sulawesi. Other species that have similar wood texture and color to D. latifolia are Pterospermum indicus (sonokembang or angsana) and $D$. sisso (sonosiso). Still, the lower wood quality compared to D. latifolia. In some parts of Indonesia, D. latifolia is named as sonobrit or sonosungu.

Dalbergia latifolia was introduced to Indonesia perhaps during the colonial era, possibly from India, and has been naturalized in several islands of Indonesia (Sunarno 1996; Maridi et al. 2014; Arisoesilaningsih and Soejono 2015;
Adema et al. 2016). The species have been cultivated mainly in agroforestry (Hani and Suryanto 2014; Mulyana et al. 2017) and monoculture plantation (Atikah and Dede 2018, unpublished). The heartwood of the rosewoods is very dense, non-porous and durable, therefore used mostly in crafting, carving, furniture, musical instruments industry (Barrett et al. 2010; Karlinasari et al. 2010; Hassold et al. 2016). The sources the wood primarily from local farmers and Forestry state-owned companies (Perhutani). The premium quality of wood was sent to the primary and secondary timber industry to be processed as semi-finished products before imported to Europe, US, Japan, and China based on information obtained from the company in East and Central Java (Yulita and Susila 2019). The low-quality pieces are utilized by the domestic market for craft, and often as firewood (Yulita and Susila 2019). This species is found in Java, mostly in East and Central part, West Nusa Tenggara, probably in lands of re-vegetation program conducted separately at different times since 1980 (Djajanti 2006; Maridi et al. 2014; Arisoesilaningsih and Soejono 2015).

The species was listed in Appendix 2 of CITES since 2017. On $2^{\text {nd }}$ January 2017, Indonesia entered reservation 
for the listing of this species and executed on $5^{\text {th }}$ July 2017 (CITES 2017), since then, D. latifolia wood products from Indonesia has received more considerable attention from the international market. Consequently, there is an increasing demand for $D$. latifolia wood from domestic supplies. The species is considered vulnerable to extinction, according to the IUCN Red List (Asian Regional Workshop 1998). Information on genetic variation is important to ensuring long-term survivorship of a species as the genetic diversity level could serve as an indicator of plant adaptability to its environment. To validate this assumption, it is, therefore, important to examine the genetic variation of some populations of $D$. latifolia. Since no study has been carried out for this purpose, this present study was aimed to assess the level of genetic diversity from five populations in Yogyakarta and Lombok Island using sequence-related Amplified Polymorphisms (SRAP). The SRAP marker was initially developed for gene tagging in Brassica oleracea $\mathrm{L}$. (Li and Quiros 2001) to amplify specific coding regions of the genome targeting GC-rich exons and AT-rich promoters, introns, and spacers. Since then, the SRAP has been widely used to detect genetic variation at various taxonomic levels including population, such as bamboo (Zhu et al. 2014), Cynodon dactylon (Zheng et al. 2017 and Gonystylus bancanus (Yulita and Rahmat 2019), intra-specific hybrid detection in wheat (Liu et al. 2008), Quantitative Trait Loci identification of Chrysanthemum (Zhang et al. 2011), species complex of Festuca-Lolium (Cheng et al. 2016), and mutant detection of Setaria italica (Yulita and Ridwan 2018). The results from this study will be used to provide insights into the genetic diversity within and among populations of $D$. latifolia that would be useful for the development of management strategies for ensuring long- term preservation and sustainable use of D. latifolia in Indonesia.

\section{MATERIALS AND METHODS}

\section{Study area}

The D. latifolia samples used in this study were collected from the Special Province of Yogyakarta (Kulon Progo and Gunung Kidul District) and Lombok Island of West Nusa Tenggara Province (West Lombok and East Lombok Districts) (Figure 1).

Dalbergia latifolia tree stands in Kulon Progo District was present in Sermo Wildlife Reserve in the altitude of $70-100 \mathrm{~m}$ asl. The forest was managed by the local Forestry Office, where the regularly monitored by the Forest Rangers, hence no illegal logging activity, has occurred. The locations were used to be a concession forest of Eucalyptus sp., Swietenia mahogani, and Tectona grandis. Nowadays, D. latifolia trees have dominated this area and formed natural stands. The mature trees have an average of $30 \mathrm{~cm}$ dbh with saplings and seedlings scattered surrounding the parent trees. Several trees reached a diameter of $80 \mathrm{~cm} \mathrm{dbh}$. The $D$. latifolia populations from Semoyo Village of Gunung Kidul District located at the altitude of $250 \mathrm{~m}$ asl and is present in a mix agroforestrymainly with Tectona grandis-managed by local farmers. The trees are locally cultivated by the farmers and owned individually by the villagers. The average diameter for the mature trees are $20-30 \mathrm{~cm}$, rarely reach more than $50 \mathrm{~cm}$ $\mathrm{dbh}$. The trees are informally protected by the villagers to ensure the sustainable use of the D. latifolia.

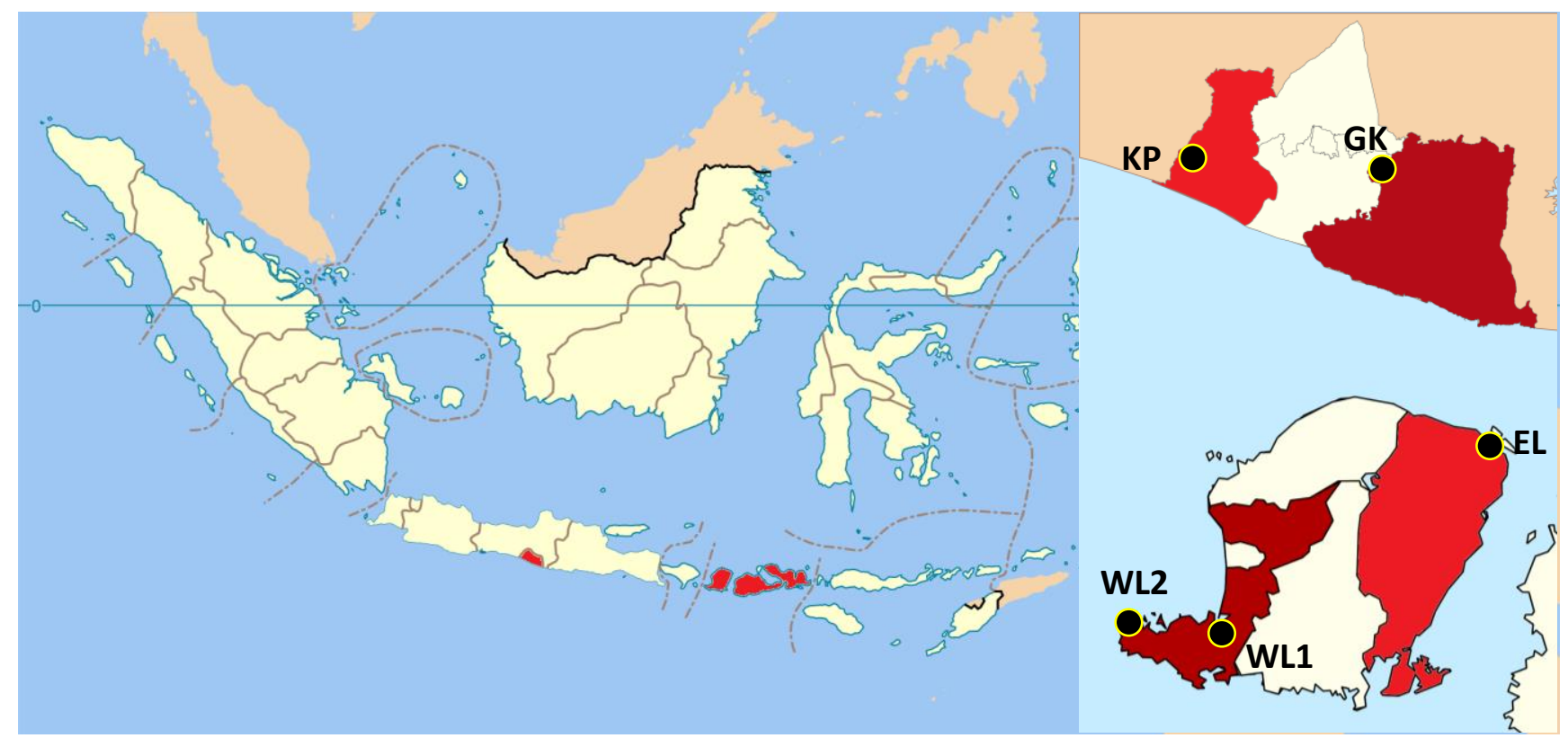

Figure 1. Locations of sampled populations from Yogyakarta and Lombok Island (West Nusa Tenggara), Indonesia 
Table 1. List of 48 samples and five populations of Dalbergia latifolia from Yogyakarta and Lombok Island, West Nusa Tenggara used in this study

\begin{tabular}{llll}
\hline No. & $\begin{array}{l}\text { Sample } \\
\text { code }\end{array}$ & Source & $\begin{array}{c}\text { Population } \\
\text { code }\end{array}$ \\
\hline $1-10$ & GK 01-10 & Semoyo Village, Patuk Subdistrict, Gunung Kidul District, Yogyakarta & GK \\
$11-13$ & KP1A-C & Sermo Wildlife Reserve, Kokap Subdistrict, Kulon Progo District, Yogyakarta & KP \\
14 & 5KP1D & Sermo Wildlife Reserve, Kokap Subdistrict, Kulon Progo District, Yogyakarta & KP \\
15 & KP1E & Sermo Wildlife Reserve, Kokap Subdistrict, Kulon Progo District, Yogyakarta & KP \\
$16-19$ & KP2A-D & Sermo Wildlife Reserve, Kokap Subdistrict, Kulon Progo District, Yogyakarta & KP \\
$20-21$ & KP3A-B & Sermo Wildlife Reserve, Kokap Subdistrict, Kulon Progo District, Yogyakarta & KP \\
$22-23$ & KP3D-E & Sermo Wildlife Reserve, Kokap Subdistrict, Kulon Progo District, Yogyakarta & KP \\
23 & KP3E & Sermo Wildlife Reserve, Kokap Subdistrict, Kulon Progo District, Yogyakarta & KP \\
24 & P1 (2) & Taman Baru Village, Sekotong Subdistrict, West Lombok District, Lombok Island & WL1 \\
25 & P1 (a) & Central Sekotong Village, Sekotong Subdistrict, West Lombok District, Lombok Island & WL1 \\
26 & P1 (b) & Central Sekotong Village, Sekotong Subdistrict, West Lombok District, Lombok Island & WL1 \\
27 & P3 & Central Sekotong Village, Sekotong Subdistrict, West Lombok District, Lombok Island & WL1 \\
$28-37$ & SP1-10 & Nature Park Bangko Bangko, Sekotong Subdistrict, West Lombok District, Lombok Island & WL2 \\
38 & SP1 (a)pt & Senang Galih Village, Sambelia Subdistrict, East Lombok District, Lombok Island & EL1 \\
49 & SP1 (b)pt & Senang Galih Village, Sambelia Subdistrict, East Lombok District, Lombok Island & EL1 \\
$40-48$ & SP2pt- & Senang Galih Village, Sambelia Subdistrict, East Lombok District, Lombok Island & EL1 \\
& 10pt & & \\
\hline
\end{tabular}

Dalbergia latifolia in Lombok Island is collected from West Lombok and East Lombok Districts. Dalbergia. latifolia from those locations has been cultivated by the local people and government as a part of the reforestation program. There are two populations at the western part (WL1 and WL2) at 19-224 $\mathrm{m}$ asl, and one population at the eastern part (EL1 at $66 \mathrm{~m}$ asl). The WL1 is managed by local farmers in mix agroforestry and monoculture system. The average tree diameter was $18.08 \mathrm{~cm}$, and the largest was $40.76 \mathrm{~cm}$. The seedling and sapling were very abundant in this area. The population of WL2 is managed by the Forestry Regional Office West Nusa Tenggara Province in a protected area and was cultivated since 1970 under the mix-agroforestry system. Seedling and sapling were also very abundant. The average diameter was 21.43 $\mathrm{cm}$, and several trees reached $40 \mathrm{~cm}$ in diameter. Meanwhile, the population in the eastern part (EL1) is managed by a private company using a monoculture system. The largest tree diameter was $44.11 \mathrm{~cm}$, with the average tree diameter was of $32.07 \mathrm{~cm}$.

\section{Samples}

A total of 48 samples were collected from five populations in Yogyakarta and Lombok Island (Figure 1, Table 1). Samples for molecular work that were collected in the field were taken from the fresh young leaves stored and dried in silica gel. Voucher specimens were made in spirit collections, and the species identification was carried out in the Herbarium Bogoriense.

\section{Molecular work}

Total genomic DNA was isolated from collected leaf material using the Genomic DNA Mini Kit (Plant) from GeneAid. PCR amplification of the total genomic DNA was performed using ten combinations of SRAP primers (Table 2) (Li and Quiros 2001). A $15 \mu \mathrm{L}$ total volume of PCR reaction composed a $1 \mathrm{x}$ PCR master mix (Green
Master Mix Promega), 10 ng DNA template, and $2 \mu \mathrm{M}$ of each primer. The optimum condition for PCR amplification was initiated by a predenaturation of $94^{\circ} \mathrm{C}$ for $5 \mathrm{~min}$, and the initial 5 cycles consisted of denaturation at $94^{\circ} \mathrm{C}$ for 1 $\min , 35^{\circ} \mathrm{C}$ for $1 \mathrm{~min}$, and $72^{\circ} \mathrm{C}$ for $2 \mathrm{~min}$. This was followed by the main amplification of 30 cycles, and each cycle consisted of a denaturation phase at $94^{\circ} \mathrm{C}$ for $1 \mathrm{~min}$, annealing phase at $50^{\circ} \mathrm{C}$ for $1 \mathrm{~min}$, and an extension phase at $72^{\circ} \mathrm{C}$ for $1 \mathrm{~min}$. The reaction was terminated by a final extension at $72^{\circ} \mathrm{C}$ for $5 \mathrm{~min}$. The PCR products (amplicons) were visualized using $1.5 \%$ agarose gel stained in GelRed (Biotium), then run electrophoretically in 1x TBE buffer at 150 Volt for $90 \mathrm{~min}$ then photographed using gel documentation system (Atto Bioinstrument).

\section{Data analysis}

The SRAP profiles were observed from electrophoretic gel photos, and the cleared and observable bands were score 1 for present and 0 for an absent band. The scored data matrix was compiled in Excel software and used for further analyses. The polymorphic information content for each population and SRAP marker was following (Zheng et al. 2017) a maximum of the value of Polymorphism Information Content (PIC) for dominant markers is 0.5 for $f$ $=0.5$ (Riek et al. 2001). A cluster analysis was performed using UPGMA (Unweighted Pair Group Method with Arithmetic Average) (Sneath and Sokal 1973). A similarity matrix with the presence-absent data was constructed by the MVSP (Kovach 2007) based on the Jaccard similarity coefficient, a statistic used for calculating the similarity and diversity of the sample sets.

Analysis of population genetics was performed using POPGENE Version 1.3.1 (Yet et al. 1999) with the model of dominant markers and diploid individuals. Parameters used to estimate genetic diversity within populations is Percentage Polymorphic Loci (PPL) (Nei 1973), observed number of alleles per locus $\left(\mathrm{n}_{\mathrm{a}}\right)$, effective number of alleles 
per locus/gene pool $\left(\mathrm{n}_{\mathrm{e}}\right)$ (Hartl and Clark 1989), Nei's gene diversity (Heterozygozity or H) (Nei 1973), and phenotypic diversity (I) based on Shannon's information index (Lewontin 1972). Parameters used to measure genetic diversity among populations are (Nei's 1978) unbiased measures of genetic distance, the relative magnitude of differentiation among populations (GST=Dst/Ht) (Nei 1987), and gene flow (Nm) (McDermott and McDonald 1993).

\section{RESULTS AND DISCUSSION}

\section{SRAP profiles}

Ten combinations of SRAP primers generated 137 loci with $136(99.27 \%)$ are polymorphic loci (Table 2$)$. The size of the amplicons was ranged between 100-1000 bp. The PCR products that were less than $100 \mathrm{bp}$ and higher than 1000 bp generally showed ambiguous bands (by-products) and therefore omitted from the analysis. Primers pair of me3F and em5R produced the highest number (19) of amplicons, while me5F and em5R resulted in the lowest number (10) of amplicons. Differences in the numbers of amplified products obtained by a combination of primers caused by the availability of complementary nucleotides of the genome. Even though the SRAP has been claimed to targeting more specific sites (Li and Quiros 2001; Robarts and Wolfe 2014) -coding sequences- the primers only annealed to their complementary sequences randomly to a certain extent and depended upon the condition during the amplification process. During the thermal cycles, not all primers could be annealed to their complementary sequences that resulted in the absence of amplified bands and even some non-specific products. These phenomena could be caused by the slippage of DNA polymerase during PCR reactions that result in the insertions-deletions events (Viguera et al. 2001). Therefore the scoring was only targetting DNA bands that are visible to avoid the bias for scoring the non-specific amplicons.

The amplified DNA band showed different resolutions of the visible bands (Figure 2). This may due to the different quantity of DNA genomes as templates for PCR reactions and competition of primers to anneal their complementary sequence of the template DNA, thus yielded the different amount of the amplified products. Hence each band of the SRAP profiles showed different clarity.

Table 2. List of primer used, the total number of amplified fragments and number of polymorphic fragments generated by PCR using a screened combination of SRAP primers

\begin{tabular}{|c|c|c|c|}
\hline Primer pairs and their sequence & $\begin{array}{c}\text { Total numbers } \\
\text { of amplified } \\
\text { products }\end{array}$ & $\begin{array}{c}\text { Numbers of } \\
\text { polymorphic } \\
\text { products }\end{array}$ & $\begin{array}{l}\text { Size range } \\
\text { (bp) }\end{array}$ \\
\hline me1F (TGAGTCCAAACCCGATA)+em3R (GACTGCGTACGAATTGAC) & 16 & 16 & $100-900$ \\
\hline me2F (TGAGTCCAAACCGGAGC+em3R (GACTGCGTACGAATTGCA) & 13 & 13 & $120-1000$ \\
\hline me2F (TGAGTCCAAACCGGAGC+em4R (GACTGCGTACGAATTTGA) & 16 & 16 & $100-1000$ \\
\hline me3F (TGAGTCCAAACCGGAAT)+em2R (GACTGCGTACGAATTTGC) & 11 & 11 & $120-1000$ \\
\hline me3F (TGAGTCCAAACCGGAAT)+em4R (GACTGCGTACGAATTTGA) & 15 & 15 & $100-1000$ \\
\hline me3F (TGAGTCCAAACCGGAAT)+em5R (GACTGCGTACGAATTGCA) & 19 & 19 & $100-1000$ \\
\hline me4F (TGAGTCCAAACCGGACC)+em2R (GACTGCGTACGAATTTGC) & 13 & 13 & $100-1000$ \\
\hline me4F (TGAGTCCAAACCGGACC)+em3R (GACTGCGTACGAATTGAC) & 13 & 13 & $100-900$ \\
\hline me4F (TGAGTCCAAACCGGACC)+em5R (GACTGCGTACGAATTGCA) & 11 & 11 & $120-900$ \\
\hline me5F (TGAGTCCAAACCGCAAC)+em5R GACTGCGTACGAATTGCA) & 10 & 9 & $100-1000$ \\
\hline 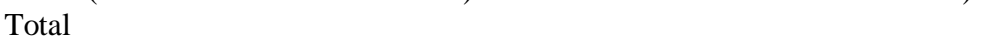 & 137 (13.7/locus) & 136 (13.6/locus) & \\
\hline
\end{tabular}

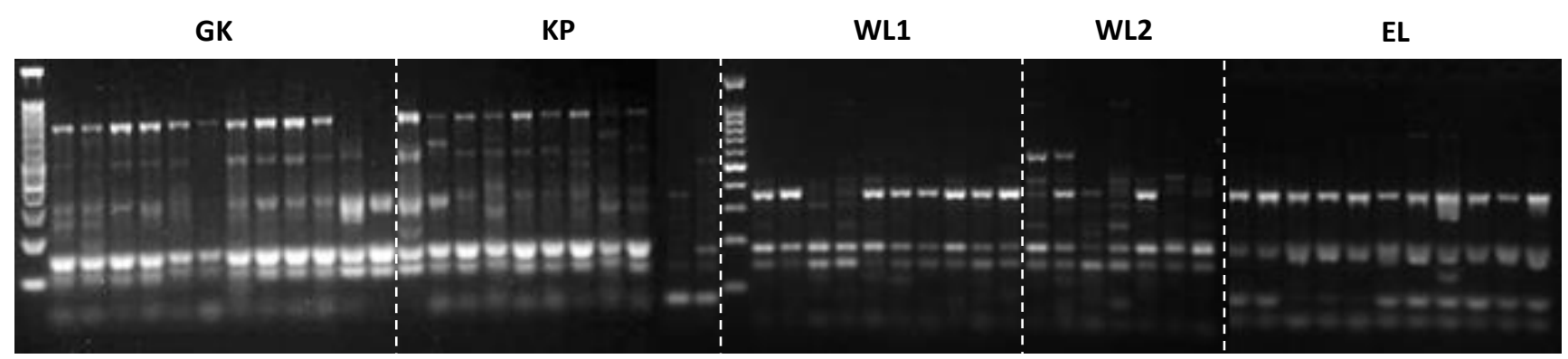

Figure 2. Photograph of SRAP profiles using primer pairs of me5F and em5R. The sequence of the sample's numbers is following Table 1. GK: Gunung Kidul population, KP: Kulon Progo population, WL1: West Lombok population, EL: East Lombok population. DNA ruler used was the 100bp DNA ladder (Genesis DL 007) 
Table 3. Summary of genetic variation statistics for all loci of Dalbergia latifolia populations from Gunung Kidul and Kulon Progo District of Yogyakarta and East and West Lombok District of Lombok Island, Indonesia

\begin{tabular}{|c|c|c|c|c|c|c|}
\hline $\begin{array}{l}\text { Population's } \\
\text { name }\end{array}$ & $\mathbf{N}^{\mathbf{b}}$ & $\begin{array}{l}\text { No of PL } \\
\text { and PLP } \\
(\%)\end{array}$ & $\mathbf{N a}^{\mathrm{d}}$ & $\mathbf{N e}^{e}$ & $\mathbf{H}^{\mathrm{f}}$ & $I^{\mathrm{g}}$ \\
\hline $\begin{array}{l}\text { Gunung } \\
\text { Kidul }\end{array}$ & 10 & $92(67.15)$ & 1.67 & 1.32 & 0.20 & 0.31 \\
\hline Kulon Progo & 13 & $97(70.80)$ & 1.71 & 1.31 & 0.19 & 0.30 \\
\hline $\begin{array}{l}\text { West } \\
\text { Lombok } 1\end{array}$ & 5 & $47(34.31)$ & 1.34 & 1.18 & 0.11 & 0.17 \\
\hline $\begin{array}{l}\text { West } \\
\text { Lombok } 2\end{array}$ & 10 & $72(52.55)$ & 1.53 & 1.22 & 0.14 & 0.22 \\
\hline $\begin{array}{l}\text { East Lombok } \\
1\end{array}$ & 11 & $77(56.20)$ & 1.56 & 1.26 & 0.16 & 0.25 \\
\hline Mean \pm SD & 10 & 77 (56.18) & 1.56 & 1.26 & 0.16 & 0.25 \\
\hline
\end{tabular}

\section{for all loci}

Note: population's name refers to Table $1 .{ }^{b} n=$ number of individuals. ${ }^{\mathrm{c}} \mathrm{PLP}=$ percentage of polymorphic loci. ${ }^{\mathrm{d}} \mathrm{N}_{\mathrm{a}}=$ Observed number of alleles. ${ }^{\mathrm{e}} \mathrm{N}_{\mathrm{e}}=$ Effective number of alleles (Kimura and Crow 1964). ${ }^{\mathrm{f}} \mathrm{H}=$ Nei's (1973) gene diversity. ${ }^{\mathrm{g}} I=$ Shannon's Information index (Lewontin 1972)

\section{Genetic diversity of Dalbergia latifolia}

Genetic diversity is generally used to describe variations found in individuals, populations, and species, and can be measured at such levels. Genetic diversity is indicated by the presence of polymorphisms at the locus. The assessment of genetic diversity is based mostly on the polymorphisms found in loci, represented by the PIC and PLP values. The PIC is a measure of allele frequencies at single loci or summed multiple loci. For the dominant markers, the PIC values range from 0 to 0.5 , where 0 indicates fixation of one allele, and 0.5 means equal frequencies of alleles (Riek et al. 2001). In the present study, the PIC value for SRAP markers ranged from 0.04 to 0.49 , with an average of 0.28 , also indicating that $D$. latifolia trees displayed a wide range of PIC with a moderate level of PIC.

The average number of polymorphic bands is 13.6 per locus, a similar value (13.8) obtained by Zheng et al. (2017) on Chinese bermudagrass (Cynodon dactylon) and this a little higher than the mean number of polymorphic loci reported for 152 studies of various plant species using SRAP (Robarts and Wolfe 2014), The moderate level of polymorphic loci (56\%) obtained from this study suggesting that SRAP marker is considered reliable to detect polymorphism both at individual and population level. The values were generally lower than those obtained in other previous studies using more random markers such as RAPD, ISSR and SSR (Rout et al. 2003; Bakshi and Sharma 2011; Cheng et al. 2016; Zheng et al. 2017). (Yulita and Rahmat 2019) considered SRAP and the other mentioned markers-e.g. RAPD-have different nature of polymorphism. The amplified products of SRAP, when firstly developed (Li and Quiros 2001) contained 45\% are known genes. The coding regions (genes) are more conserved for having a slow mutation rate than those of non-coding regions. On the other hand, the amplified products of random amplified markers may contain both parts of coding and noncoding regions, and they may have a higher level of polymorphisms than those of SRAP. The use of comparative markers for this species is, therefore, important.

The statistics used as parameters for genetic variations (Table 3) showed a considerable range of values of the statistics for populations from each island. The NPL was higher in populations of Yogyakarta than those from Lombok Island. The mean PLP value for D. latifolia was $67.15 \%$. The $\mathrm{N}_{\mathrm{a}}$ is higher than $\mathrm{N}_{\mathrm{e}}$ as expected, while the $\mathrm{H}$ and I value also showed similar trends for both islands (mean $\mathrm{I}=0.25$ and $\mathrm{H}=0.16$ ). Study on $D$. conchichinensis in Vietnam using ISSR and RAPD showed the same level of genetic diversity $(\mathrm{I}=0.206$ and $\mathrm{H}=0.156)$ to our study $(\mathrm{I}=0.25$ and $\mathrm{H}=0.16)$ for between species and a significant variation within a species (Hien and Phong 2012) to which ISSR provided more polymorphism than RAPD. The $\mathrm{H}$ and I value for each population were much less than 1 suggesting a low level of genetic diversity. Generally, populations from Yogyakarta (Gunung Kidul and Kulon Progo Districts) have a higher genetic diversity compared to those from Lombok Island (Table 3). The level of polymorphism, however, generally was related to the number of accessions and their geographic origin, with a higher level of polymorphism among more accessions from a more extensive geographic range compared to the narrower range (Zheng et al. 2017). Overall, the He and I value of Yogyakarta populations were higher than West Nusa Tenggara populations, indicating that Yogyakarta may have higher adaptability and vitality compared to populations in West Nusa Tenggara. As the D. latifolia tree stands in Kulon Progo present in a protected forest, they have less human interference than the neighbor population in Gunung Kidul of Yogyakarta to which trees were managed by the farmers in their home garden, and it is therefore anticipated that regeneration of Sonekeling trees in Kulon Progo may have been more naturally reproduced/outcrossed. Hence, the Kulon Progo populations have higher polymorphic loci. (Stojnić et al. 2019) considered populations with a high level of genetic diversity have a strong positive correlation between heterozygosity and population fitness, which is vital for the long-term adaptation of populations to novel environmental conditions. A population is more susceptible to unfavorable environmental conditions if there is a lack of heterozygosity (Basyuni et al. 2012). The population WL1 had the lowest genetic diversity $(\mathrm{H}$ was of 0.11 ) that may be due to a lack of samples collected from Sekotong Subdistrict, West Lombok District (Table 1).

The total genetic diversity in all populations $\left(\mathrm{H}_{\mathrm{T}}\right)$ was 0.22 , whereas the average genetic diversity within populations $\left(\mathrm{H}_{\mathrm{S}}\right)$ was 0.16 (Table 4$)$. By contrast, the genetic diversity between populations $\left(\mathrm{D}_{\mathrm{ST}}\right)$ is much lower (0.05) than both $\mathrm{H}_{\mathrm{T}}$ and $\mathrm{H}_{\mathrm{S}}$. These values were suggesting that the level of heterozygosity among and withinpopulation were considerably low. Based on our observations in several populations, D. latifolia were mainly reproduced vegetatively from root cutting, and in one population in Yogyakarta, the flowers have never seen to set fruits. This phenomenon may be caused by intensive 
domestication in the past resulted in decreasing the ability of this species to reproduce generatively; thus, one can expect a low level of heterozygosity within the trees and populations studied. Such conditions would not be suitable for the survivorship of the species since the homogenous populations are more prone to internal and external pressure, such as pests and diseases.

The results from this study showed considerable variations in SRAP profiles, and a low level of genetic diversity could still be observed, and this may be suggested there are still cross-pollinations that occurred to a certain extent, even though maybe at a low level. Genetic differentiation between the populations $\left(\mathrm{F}_{\mathrm{ST}}\right)$ was $27 \%$, which is considered intermediate, whereas gene flow $(\mathrm{Nm})$ between the populations was as low as 1.31 (Table 4), which reflects the restricted pollination system of $D$. latifolia. Cross-pollination between plants having a small genetic distance or closed relationship can increase homozygosity. In contrast, cross-pollination between plants with high genetic distance or distantly related can increase heterozygosity (Whitlock 2011).

\section{Genetic distance among the population and individual Dalbergia latifolia from Yogyakarta and Lombok Island}

Genetic differences between populations and individuals are measured by the genetic differentiation or genetic distance and further demonstrated by the clustering method. Genetic distances can be used to measure differences in genetic structure between two individuals or populations at a particular gene locus. Genetic distance is the degree of gene (genomic) difference between species or populations that can be measured by numerical method. This method was established as a major tool for data analysis on genetic differentiation. Therefore, genetic diversity between individual accessions was used to construct the dendrogram of individuals in clustering trees based on the similarity matrix (in this case, using the Jaccard similarity coefficient) using the UPGMA method. Genetic distance for the five populations of $D$. latifolia is summarized in Table 5, while the genetic similarity of each individual is presented in a UPGMA dendrogram (Figure $3)$. The highest genetic distance $(0.1281$, Table 5) were observed between population WL1 and GK, indicating the dissimilarity between those populations was quite far. Meanwhile, the lowest genetic distance (0.0310) was recorded between population GK and KP.

The UPGMA dendrogram of populations of D. latifolia showed that the East Lombok is the most distinct population since it does not form a group with any of the remaining populations. Meanwhile, populations of GK and KP, and WL1 and WL2 formed a group that was in accordance to their island of origin (Figure 3). The EL population has a considerably higher pairwise genetic distance against each population (Table 5); this could explain the position of EL at the basal dendrogram. A closer examination on the SRAP profiles did not show any particular unique bands possessed by the EL population (data not shown), and this was supported by the cluster and PCA analyses (Figure 4 and 5) to which no clear separations between the WL and EL populations and that the EL population was part of the WL group. The results from the PCA analysis were further suggested that there were no characters (in this case, SRAP bands) defined the EL population inclusively. Hence, the separation of the EL from the WL population in the population genetic analysis was merely due to their higher genetic distances based on the pairwise distance analysis.

The genetic similarity among individuals is represented by the results of cluster analysis (Figure 4) to which all trees were united at the range of ca. 0.2-0.70 coefficient of similarity. The most distinct tree was KP 18, located within the Yogyakarta 1 group, and the most similar trees are SP8 and SP 9 for having ca. $70 \%$ similarity belonging to the EL population. All trees, therefore, have a moderate range of similarity (ca. 50\%). The UPGMA dendrogram showed there are three groups of $D$. latifolia, one group consisted of inclusively individuals from West Nusa Tenggara, while the other two groups are populations from Yogyakarta (Figure 4). Three individuals from Yogyakarta's population ( 1 from Gunung Kidul and 2 from Kulon Progo) are separated from the main Yogyakarta's group with low coefficient similarity (ca. 0.2).

Meanwhile, the populations of Lombok Island were united as a group based on ca. 0.28 similarity coefficient with a further grouping of West Lombok and East Lombok were observed from this cluster (Figure 3). Each of the Lombok and the main Yogyakarta's formed a group based on an almost similar value of coefficient similarity (ca. 0.4). A similar value of similarity coefficient (ca. 50\%) was observed in Dalbergia sisso from Lacchiwala India by using RAPD (Bakshi and Sharma 2011).

Table 5. Genetic identity (above diagonal) and genetic distance (below diagonal) based on Nei's Unbiased Measures (Nei 1978)

\begin{tabular}{llllll}
\hline Population & GK & KP & WL1 & WL2 & EL \\
\hline GK & - & 0.9695 & 0.8798 & 0.8812 & 0.8785 \\
KP & 0.0310 & - & 0.9074 & 0.9011 & 0.8990 \\
WL1 & 0.1281 & 0.0971 & - & 0.9689 & 0.9439 \\
WL2 & 0.1265 & 0.1041 & 0.0316 & - & 0.9632 \\
EL & 0.1295 & 0.1064 & 0.0578 & 0.0375 & - \\
\hline
\end{tabular}

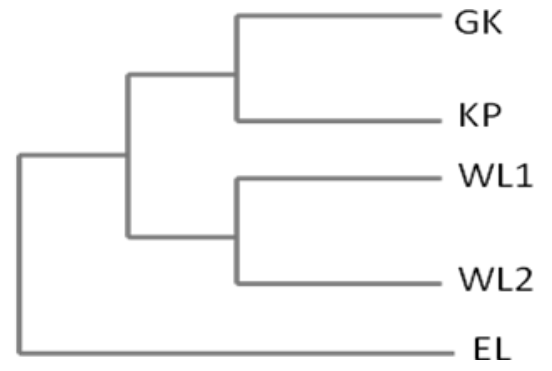

Figure 3. UPGMA dendrogram of five populations of Dalbergia latifolia from Yogyakarta (GK and KP) and Lombok Island (WL1, WL2, and EL) based on SRAP profiles using Nei and Li's coefficient of distance 
Table 4. Statistics for analysis of gene diversity (Nei 1987) in sub-divided populations

\begin{tabular}{lccccc}
\hline Sample size & $\mathbf{H}_{\mathbf{T}}$ & $\mathbf{H}_{\mathbf{S}}$ & $\mathbf{D}_{\text {ST }}$ & $\mathbf{F}_{\text {ST }}$ & $\mathbf{N}_{\mathbf{e}} \mathbf{m}$ \\
\hline 49 & $0.2211 \pm 0.0236$ & $0.1600 \pm 0.0119$ & 0.0611 & 0.2760 & 1.3115 \\
\hline
\end{tabular}

Note: $\mathrm{H}_{\mathrm{T}}$ : Total gene diversity, $\mathrm{H}_{\mathrm{S}}$ : expected heterozygosity in each population, Dsт: expected heterozygosity in among populations,

FST: genetic differentiation (for diallelic locus), $\mathrm{N}_{\mathrm{e}}$ m: effective immigration per generation (Hamrick and Nason 2000)

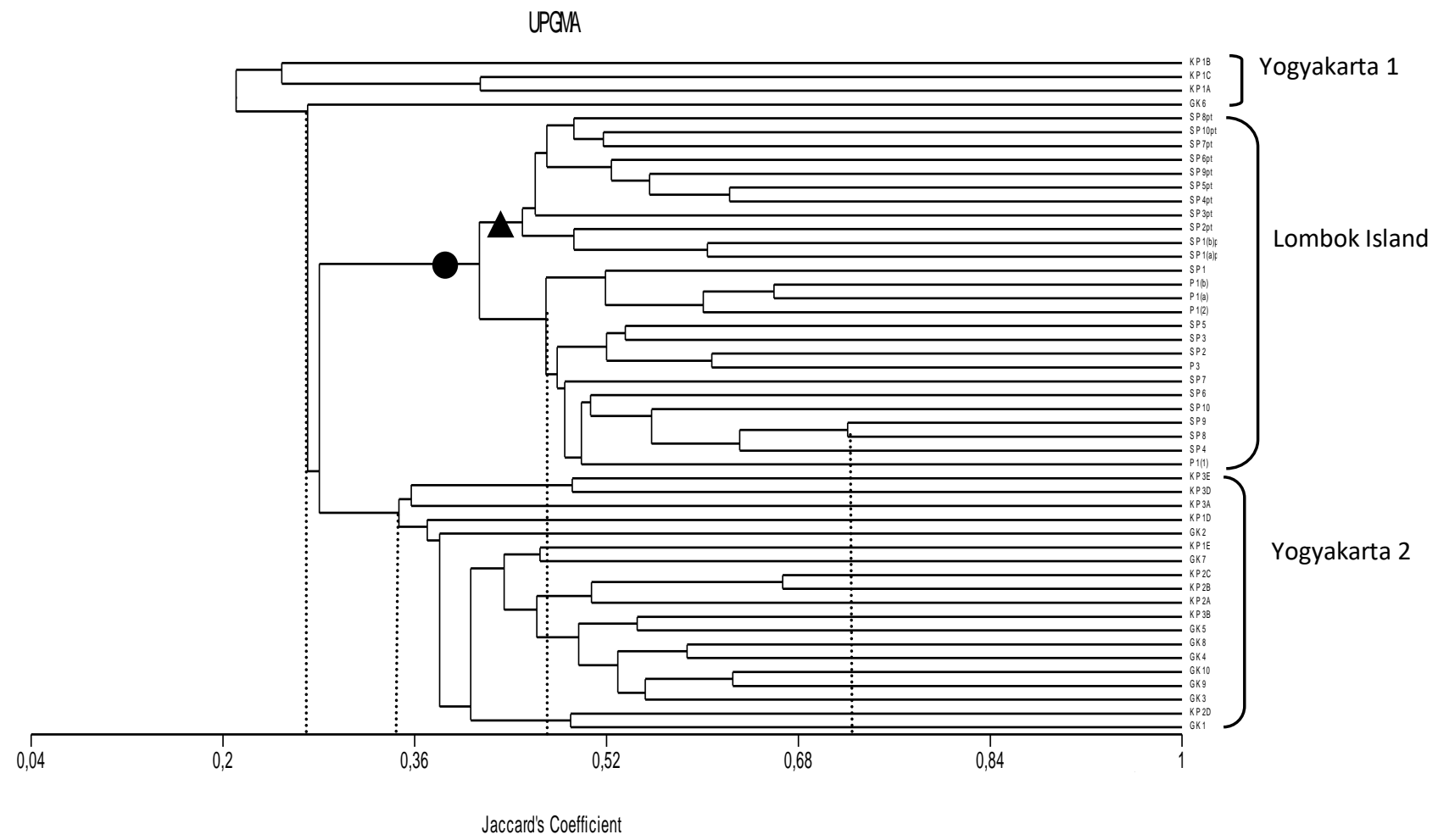

Figure 4. The UPGMA dendrogram of 48 Dalbergia latifolia trees from Yogyakarta and Lombok Island based on SRAP profiles using the Jaccard similarity coefficient. Black dot symbol representing Lombok populations forming one group with East Lombok population is nested within (Black triangle)

However, the results from the PCA (Figure 5) showed that both populations are separated into two distinct groups located at positive $\mathrm{X}$-axis, but at different $\mathrm{Y}$-axis, Yogyakarta is at a positive Y-axis, while the West Nusa Tenggara is at negative $\mathrm{Y}$-axis. More than $50 \%$ of SRAP bands cannot define the two groupings-revealed by their positions at negative X-axis-, only ca. 15 SRAP bands that clearly defined the Yogyakarta's group and ca. 18 bands tend to define the Lombok group (Figure 4).

The grouping pattern drawn from the UPGMA dendrogram both at the population (Figure 2) and individual level (Figure 3) indicated that the SRAP profiles resulted from this study are reliable enough to distinguish populations and detected sufficient variations among individual trees. The considerable variations in SRAP profiles and low level of genetic diversity that could still be observed in this study have suggested there are still cross- pollinations that occurred to a certain extent, even though maybe at a low level. This is a significant finding that cultivation practices should not merely be done using vegetative propagation. The plantation should also include populations containing different genetic variations to allow cross-pollination to occur to maintain long-term preservation and sustainable use of $D$. latifolia in Indonesia.

It can be concluded that restricted Dalbergia latifolia that grow in Yogyakarta and Lombok Island had a low level of genetic diversity $(\mathrm{H}=0.13)$, a moderate level of genetic differentiation (Fst $=27 \%$ ) and considerable variations among individual trees that reflected by ca. $50 \%$ similarity among the trees. Dalbergia latifolia in the populations' studies showed with restricted gene flow among the five populations and may tend to mate among individuals within the populations. 


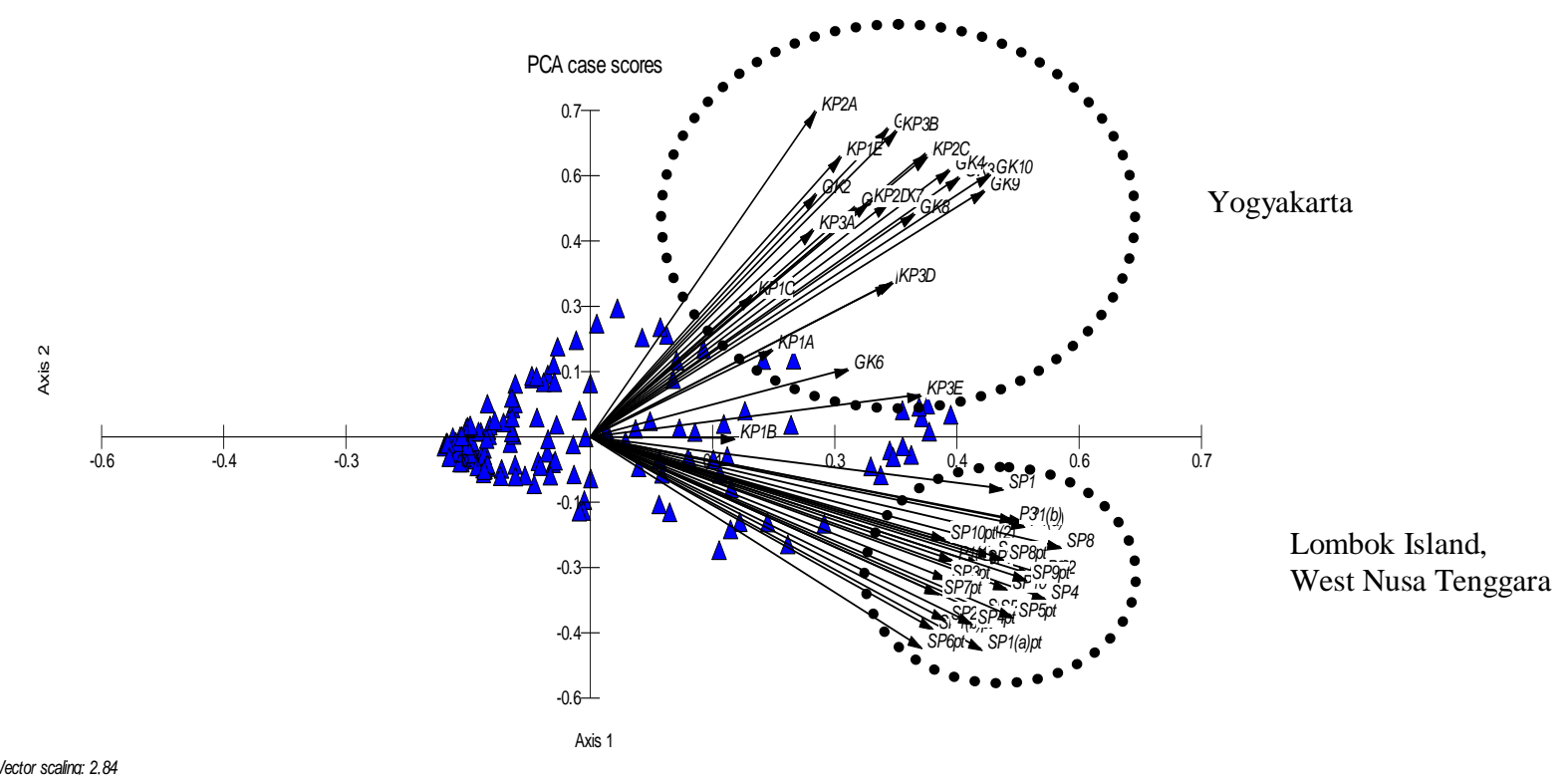

Figure 5. The PCA diagram of 48 Dalbergia latifolia trees from Yogyakarta and West Nusa Tenggara based on SRAP profiles. Small triangles symbol represented SRAP bands. Positions of the triangle defined and support the grouping indicated by circles.

\section{ACKNOWLEDGEMENTS}

This study was supported by the KSK CITES Monitoring Study Wildlife listed in CITES Appendices with its economic and anthropological aspects of the Research Centre for Biology. We thank the Regional Office of Conservation on Natural Resources (BKSDA) of Yogyakarta, Resort of Conservation Area of Kulon Progo, Mr. Suratimin, and Mr. Mustanadi of BKSDA West Nusa Tenggara. We appreciated the assistance of blind reviewers for their critical and constructive comments for the improvement of this manuscript and the work in general.

\section{REFERENCES}

Adema F, Ohashi H, Sunarno B. 2016. Notes on Malesian Fabaceae 17. The Genus Dalbergia. Blumea 61: 186-206

Arisoesilaningsih E, Soejono S. 2015. Diversity of drought-resistant plants and the benefits of their biomass for improving fertility of degraded soil of Brantas River Basin. J Degraded Mining Land Manag 2 (2): 313-318.

Asian Regional Workshop (Conservation \& Sustainable Management of Trees, Viet Nam, August 1996). 1998. Dalbergia latifolia. The IUCN Red List of Threatened Species 1998: e.T32098A9675296. DOI: 10.2305/IUCN.UK.1998.RLTS.T32098A9675296.en

Atikah TD, Dede S. 2018. A population study and trade of Dalbergia latifolia in Lombok, West Nusa Tenggara Province. Field report. Research Centre for Biology, Indonesian Institute of Sciences.

Bakshi M, Sharma A. 2011. Assessment of genetic diversity in Dalbergia sissoo clones through RAPD profiling. J For Res 22 (3): 393-397. DOI 10.1007/s11676-011-0183-7

Basyuni M, Hamzah, Rahayu S, Siregar UJ. 2012. Effect of anthropogenic activities on genetic variation of Rhizophora mucronata Lamk. in Secanggang Mangrove Forest, North Sumatra. FORESTA 1 (2): 41 48.

Barrett MA, Brown JL, Morikawa MK, Labat J, Yoder AD. 2010. CITES Designation for endangered rosewood in Madagascar. Science 328: 1109-1110.
Cardoso D, Pennington RT, de Queiroz LP, Boatwright JS, Van Wyk BE, Wojciechowski MF, Lavin M. 2013. Reconstructing the deepbranching relationships of the papilionoid legumes. South Afr J Bot 89: $58-75$.

Cheng Y, Ma X, Zhou K, Humphreys MW, Zhang XQ. 2016. Phylogenetic analysis of Festuca-Lolium complex using SRAP markers. Genet Resour Crop Evol 63: 7-18. DOI 10.1007/s10722015-0324-5

CITES. 2017. Notification to the parties. https://cites.org/sites/default/files/notif/E-Notif-2017-010.pdf

Djajanti D. 2006. Managing Forest with Community (PHBM) in Yogyakarta: Promoting Equity in Access to NTFPs. In: Mahanty S, Fox J, Nurse N, Stephen P, McLees L (eds) Hanging the Balance: Equity in Community-Based Natural Resource Management in Asia. Recoftc \& East-West Center.

Hamrick JL, Nason JD. 2000. Gene Flow in Forest Trees. Forest conservation genetics: principles and practice. pp.81-90.

Hani A, Suryanto P. 2014. The dynamics of agroforestry in the Hills of Manoreh, Kulon Progo, Yogyakarta Province. J Penelitian Kehutanan Wallacea 3 (2): 119-128. [Indonesian]

Hartl DL, Clark AG. 1989. Principles of population genetics. 2nd ed. Sinauer Associates, Sunderland, Massachusetts.

Hassold S, Lowry PP, Bauert MR, Razafintsalama A. 2016. DNA barcoding of Malagasy rosewoods: towards a molecular identification of CITES-listed Dalbergia species. PLoS One 11: e0157881. DOI: 10.1371/journal.pone.0157881

Hien VTT, Phong DT. 2012. Genetic diversity among endangered rare Dalbergia cochinchinensis (Fabaceae) genotypes in Vietnam revealed by random amplified polymorphic DNA (RAPD) and inter simple sequence repeats (ISSR) markers. Afr J Biotechnol 11 (35): 86328644. DOI: $10.5897 / A J B 11.3598$

Karlinasari L, Nawawi DS, Widyani M. 2010. Study of the anatomy and wood chemistry in relation to the acoustic properties of wood. Bionatura 12 (3): 110-116. [Indonesian]

Kimura M, Crow JF. 1964. The number of alleles that can be maintained in a finite population. Genetics 49: 725-738.

Kovach WL. 2007. MVSP A multivariate statistical package for windows ver 3.1. Kovach Computing Services. Pentraeth, Wales, UK.

Lewontin RC. 1972. The apportionment of human diversity. J Evol Biol 6: 381-398.

Li G, Quiros F. 2001. Sequence-related amplified polymorphism (SRAP), a new marker system based on a simple PCR reaction: its application 
to mapping and gene tagging in Brassica. Theor Appl Genet 103: 455461.

Li Q, Wu J, Wang Y, Lian X, Wu F, Zhou L, Huang Z, Zhu S. 2017. The phylogenetic analysis of Dalbergia (Fabaceae: Papilionaceae) based on different DNA barcodes. Holzforschung 71 (12): 939-949.

Liu Y, Yan H, Yang W, Li X, Li Y, Meng Q, Zhang L, et al. 2008. Molecular diversity of 23 wheat leaf rust resistance near-isogenic lines determined by sequence-related amplified polymorphism. Sci Agric Sin 41: 1333-1340.

Maridi, Agustina P, Saputra A. 2014. Vegetation analysis of Samin Watershed, Central Java as water and soil conservation efforts. Biodiversitas 15 (2): 215-223.

McDermott JM, McDonald BA. 1993. Gene flow in plant pathosystems. Annu Rev Phytopathol 31: 353-373.

Mulyana L, Febryano IG, Safe'I R, Banuwa IS. 2017. Performance of agroforestry management in the Rajabasa protected forest management unit. J Hutan Tropis 5 (2): 127-133. [Indonesian]

Nei M. 1973. Analysis of gene diversity in subdivided populations. Proceedings of the National Academy Sciences USA 70: 3321-3323.

Nei M. 1978. Estimation of average heterozygosity and genetic distance from a small number of individuals. Genetics 89: 583-590.

Nei M. 1987. Molecular Evolutionary Genetics. Columbia University Press, New York.

Riek JD, Calsyn E, Everaert I, Bockstaele EV, Loose MD. 2001. AFLP based alternatives for the assessment of Distinctness, Uniformity, and Stability of sugar beet varieties. Theor Appl Genet 103: 1254-1265.

Robarts DWH, Wolfe AD. 2014. Sequence-Related Amplified Polymorphism (SRAP): A potential resource for studies in plant molecular biology. Appl Plant Sci 2 (7): 1400017

Rout GR, Bhattacharya D, Nanda RM, Nayak S, Das P. 2003. Evaluation of genetic relationships in Dalbergia species using RAPD markers. Biodivers Conserv 12: 197-206.

Saha S, Shilpi JA, Mondal H, Hossain F, Anisuzzman M, Hasan MM, Cordell GA. 2013. Ethnomedicinal, phytochemical, and pharmacological profile of the genus Dalbergia L. (Fabaceae). Phytopharmacology 4: 291-346.

Sneath PHA and Sokal RR 1973 Numerical taxonomy-the principles and practice of numerical classification. WH Freeman, San Francisco.

Stojnić S, Avramidou EA, Fussi B, Westergren M, Orlović S, Matović B, Trudi' B, Kraigher H, Aravanopoulos FA, Konnert M. 2019. Assessment of genetic diversity and population genetic structure of
Norway spruce (Picea abies (L.) Karsten) at its Southern Lineage in Europe. Implications for Conservation of Forest Genetic Resources Forests. For Policy Biodivers Strategy 10 (3): 258. doi: 10.3390/f10030258

Sunarno B. 1996. Systematic Studies of Malesian Dalbergia (Leguminosae). [PhD Dissertation]. Tohoku University, Japan.

Vatanparast M, Klitgard BB, Adema FACB, Pennington RT, Yahara T, Kajita T. 2013. First molecular phylogeny of the pantropical genus Dalbergia: implications for infrageneric circumscription and biogeography. South Afr J Bot 89: 143-149.

Viguera E, Canceill D, Ehrlich SD. 2001. In vitro Replication Slippage by DNA Polymerases from Thermophilic Organisms. J Mol Biol 312: 323-333. DOI: $10.1006 /$ jmbi.2001.4943 a.

Whitlock MC. 2011. GST and D does not replace FST. Mol Ecol 20 (6): 1083-1091.

Yeh FC, Yang R, Boyle T. 1999. POPGENE, Microsoft Window-based Freeware for Population Genetic Analysis. Version 1.31, University of Alberta, Edmonton, Canada.

Yulita KS, Rahmat HH. 2019. Population genetic structure and diversity of a critically endangered Ramin [Gonystylus bancanus Miq. (Kurz), Thymelaeaceae] from Kalimantan and Sumatra based on Sequence Random Amplified Polymorphism. IOP Conf Ser: Earth Environ Sci 308: 012067. DOI: $10.1088 / 1755-1315 / 308 / 1 / 012067$

Yulita KS, Ridwan. 2018. Molecular characterization of induced mutation of jewawut (Setaria italica ssp. italica) from Buru Island, Indonesia, using SRAP. Biodiversitas 19 (3): 1160-1168.

Yulita KS, Susila. 2019. Field collection and monitoring of the flowering of Sonokeling (Dalbergia latifolia) in Yogyakarta and East Java Provinces. Field report. Research Centre for Biology, Indonesian Institute of Sciences, Bogor. [Indonesian].

Zhang F, Chen S, Chen F, et al. 2011. SRAP-based mapping and QTL detection for inflorescence-related traits in chrysanthemum (Dendranthema morifolium). Mol Breeding 27: 11-23. DOI: 10.1007/s11032-010-9409-1.

Zheng Y, Xu S, Liu J, Zhao Y, Liu J. 2017. Genetic diversity and population structure of Chinese natural bermudagrass [Cynodon dactylon (L.) Pers.] germplasm based on SRAP markers. PLoS ONE 12 (5): e0177508. DOI: 10.1371/journal.pone.0177508.

Zhu S, Liu T, Tang Q, Fu L, Tang S. 2014. Evaluation of Bamboo Genetic Diversity Using Morphological and SRAP Analyses. Russian Journal of Genetics 50 (3): 267-273. DOI: 10.1134/S1022795414030132. 